\title{
Management of groundwater in the Nobi Plain that modeled groundwater use for earthquake disasters and environmental preservation
}

\author{
Kenji Daito \\ Department of Integrated Informatics, Daido University, 457-8532, Nagoya, Japan \\ Correspondence: Kenji Daito (daito@daido-it.ac.jp) \\ Published: 22 April 2020
}

\begin{abstract}
The pumped discharge of groundwater increased rapidly in Japan during the period of fast economic growth since the beginning of the 1960s. As a result, land subsidence has been observed, including throughout the Nobi Plain. Laws have led to restrictions on the collection of underground water, and pumped discharge has gradually reduced. In recent years, the groundwater level that had formerly decreased has begun to rise again, leading to less land subsidence. However, as groundwater levels rise, the occurrence of new problems is feared, such as the danger posed by liquefaction. In this study, an analysis was conducted on the changes in the state of groundwater based on future groundwater-use scenarios and forecasts of land subsidence. This involved thinking about the effective use of groundwater to prevent excessive rises in groundwater levels, using a three-dimensional groundwater-flow analysis and a perpendicular one-dimensional subsidence consolidation analysis. As a result, it was shown that it would be beneficial to use groundwater as a means of continuous environmental preservation and as the water resource at the earthquake disaster. At this time new wells were set up at the refuge of the disaster specified in the Nobi Plain. And the remarkable land subsidence was not caused by pumped discharge.
\end{abstract}

\section{Introduction}

Groundwater has been used for various purposes and has long been a valuable water resource in Japan. Although groundwater has been used for a long time by many people, the pumped discharge of groundwater increased rapidly during the period of high economic growth experienced since the beginning of the 1960s. This was also true in the Nobi Plain, where abundant groundwater was extracted for use in industries such as the steel industry. As a result, groundwater was extracted from almost the entire area, and subsidence of the plains was observed. The pumped discharge was gradually reduced by restrictions on groundwater collection enforced both in law and the local ordinances. In recent years, the groundwater level has begun to increase again, and the occurrence of subsidence has simultaneously started to decrease. However, because of the rising groundwater levels, the occurrence of new problems, such as liquefaction, is feared.
This study aimed to propose ways to manage large-scale groundwater management by investigating groundwater state changes based on future groundwater-use scenarios. It also aimed to forecast changes in the ground by thinking about the effective use of groundwater to prevent groundwater levels rising excessively by using three-dimensional groundwaterflow analysis and perpendicular one-dimensional consolidation subsidence analysis.

\section{Effective use of groundwater}

Groundwater offers various advantages. Changes in the temperature of groundwater are small. Groundwater can be easily accessed by digging wells. Safe, delicious groundwater has become more easily available in recent years as groundwater pumping technology and film filtration technology have developed. Groundwater is used in municipal water supplies, as familiar water in the parks using spring water and measures of a heat island and for improving water quality by discharging it to rivers and ponds. Moreover, groundwa- 
ter is highly valuable as a water resource to supply water following a disaster. The well water at schools and parks where there had been limited earthquake damage was used as drinking water and as water for daily life in refuges, in place of water from waterworks that were out of action because the water supply had been cut off following the Great Hanshin-Awaji Earthquake Disaster in 1995. It is feared that another great earthquake will occur in the near future. When this great earthquake occurs, water shortages are expected because there will be interruptions to water supply networks. To model this, the following conditions were assumed in this study. After a disaster such as the Tokai earthquake occurs, wells are set up in the refuges of each municipality. Pumped groundwater is usually used for both waterworks and environmental water as well as being used for drinking water and daily life in the disaster zone.

\section{Groundwater-flow analysis and consolidation analysis}

The changes in groundwater state when new wells were established in refuges was predicted based on a threedimensional groundwater-flow analysis of the Nobi Plain (Yasuhiro et al., 2005). The area covered by the analysis was $1164 \mathrm{~km}^{2}$ and includes most of the Nobi Plain, as shown in Fig. 1. In the analysis, it was assumed that a new well was established in each refuge that was within the area analyzed. Figure 2 shows the distribution of the refuges in the area analyzed. Once set up, the wells were in continuous operation, and it is assumed that the pumped groundwater is usually used as environmental water but is also used as water for daily life during a disaster. It was assumed that these wells began operating in 2008. In this analytical area, there was a total of 1663 refuges set up by municipalities during times of disaster. The pump discharge in each well was based on the amount of the water supply per person that was the volume of water of the target of the emergency water supply at the disaster in the city of Nagoya. The assumed amounts of water supplied were $3 \mathrm{Ld}^{-1}$ (Case 1), $20 \mathrm{Ld}^{-1}$ (Case 2), $100 \mathrm{Ld}^{-1}$ (Case 3) and $250 \mathrm{Ld}^{-1}$ (Case 4). Table 1 shows the number of evacuees in each refuge (the population of each municipality divided by the number of refuges). Moreover, the pumped groundwater per person of each case multiplied the number of evacuees in each refuge and the amount of groundwater pumped in a place in each refuge were calculated. The amount of the pumped groundwater after the new wells had operated was calculated. The amount of the pumped groundwater from new wells was added to that amount of the existing pumped groundwater. Table 2 shows the amount of groundwater pumped after the well had been operating. The ground-level change in each case in the vicinity of Jushiyama observation well, shown in Fig. 1, where remarkable levels of subsidence had been observed in the past, was predicted based on the perpendicular one-dimensional

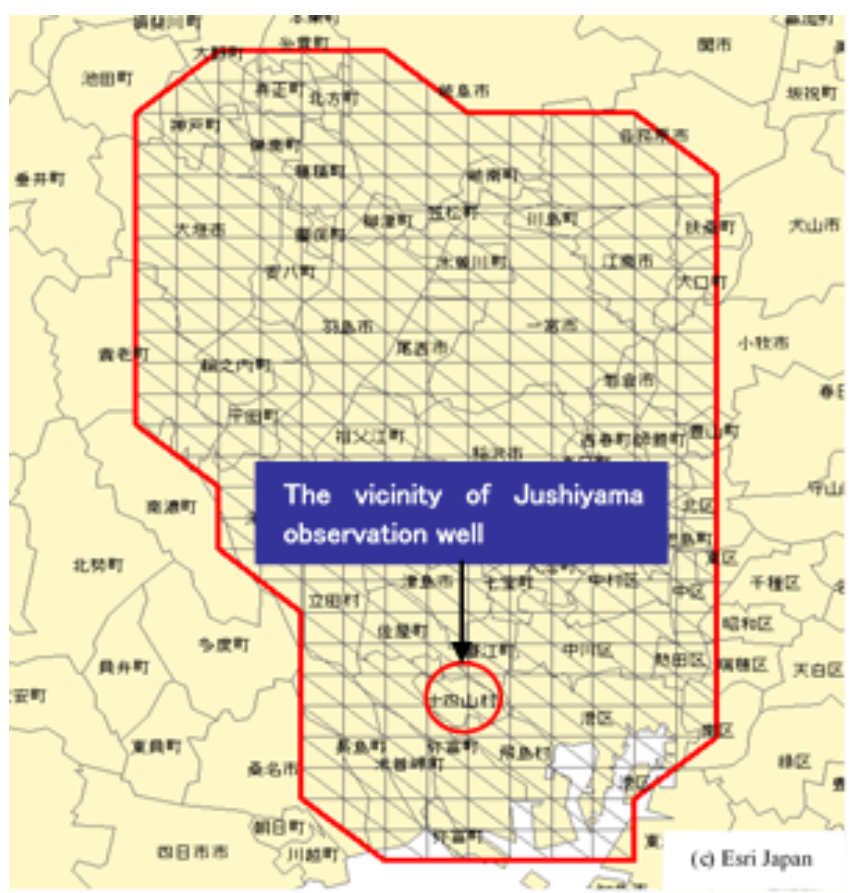

Figure 1. Analysis area.

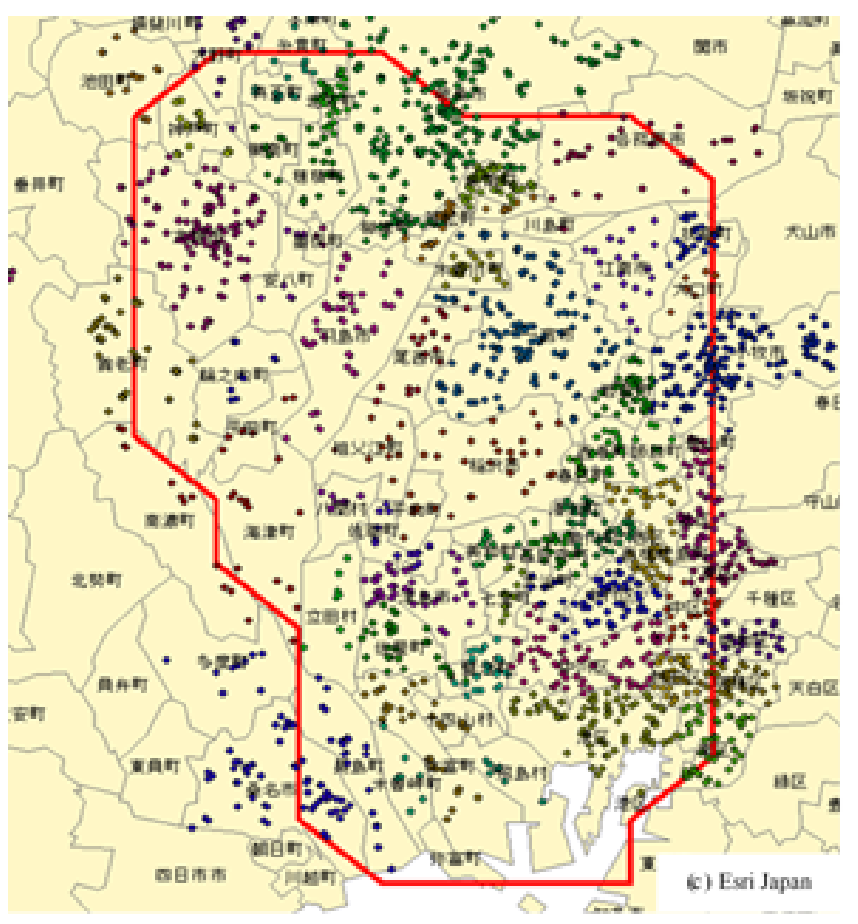

Figure 2. Analysis area and distribution of refuges.

consolidation subsidence analysis of the Nobi Plain (Kenji et al., 1992). 
Table 1. Number of evacuees in each place.

\begin{tabular}{|c|c|c|}
\hline $\begin{array}{l}\text { Municipality } \\
\text { name }\end{array}$ & $\begin{array}{r}\text { Number of } \\
\text { refuges }\end{array}$ & $\begin{array}{r}\text { Number of evacuees } \\
\text { per place }\end{array}$ \\
\hline District of Atsuta & 27 & 2307 \\
\hline District of Kita & 31 & 3324 \\
\hline District of Showa & 6 & 3285 \\
\hline District of Nakagawa & 71 & 3076 \\
\hline District of Naka & 19 & 3804 \\
\hline District of Nakamura & 48 & 2812 \\
\hline District of Nishi & 50 & 2872 \\
\hline District of Higashi & 8 & 2601 \\
\hline District of Mizuho & 5 & 3642 \\
\hline District of Minato & 74 & 2026 \\
\hline District of Minami & 19 & 2854 \\
\hline City of Aisai & 65 & 1032 \\
\hline City of Ichinomiya & 173 & 2209 \\
\hline City of Inazawa & 41 & 3379 \\
\hline City of Iwakura & 40 & 1188 \\
\hline Town of Oguchi & 6 & 3097 \\
\hline Town of Oharu & 13 & 2270 \\
\hline Town of Kanie & 28 & 1263 \\
\hline Town of Kisozaki & 7 & 848 \\
\hline City of Kitanagoya & 29 & 2872 \\
\hline City of Kiyosu & 37 & 1534 \\
\hline City of Konan & 20 & 5081 \\
\hline City of Komaki & 55 & 1126 \\
\hline Town of Shippo & 12 & 1935 \\
\hline Town of Jimokuji & 23 & 1744 \\
\hline City of Tsushima & 39 & 1711 \\
\hline Village of Tobishima & 8 & 559 \\
\hline Town of Toyoyama & 13 & 1002 \\
\hline Town of Haruhi & 10 & 776 \\
\hline Town of Fuso & 18 & 1446 \\
\hline Town of Miwa & 14 & 1744 \\
\hline City of Yatomi & 34 & 1339 \\
\hline Town of Anpachi & 7 & 2197 \\
\hline Town of Ikeda & 2 & 1643 \\
\hline City of Ogaki & 106 & 1357 \\
\hline Town of Ono & 4 & 940 \\
\hline City of Kaizu & 19 & 1255 \\
\hline City of Kakamigahara & 23 & 4372 \\
\hline Town of Kasamatsu & 28 & 841 \\
\hline Town of Kitagata & 30 & 600 \\
\hline Town of Ginan & 44 & 518 \\
\hline City of Gifu & 175 & 1406 \\
\hline Town of Godo & 20 & 1019 \\
\hline City of Hashima & 50 & 1379 \\
\hline City of Mizuho & 26 & 1859 \\
\hline City of Motosu & 13 & 1218 \\
\hline Town of Yoro & 18 & 726 \\
\hline Town of Wanouchi & 9 & 1075 \\
\hline City of Kuwana & 46 & 1609 \\
\hline Total & 1624 & \\
\hline
\end{tabular}

Table 2. Amount of groundwater pumped in the refuges in each municipality.

\begin{tabular}{|c|c|c|c|c|}
\hline \multirow[t]{2}{*}{$\begin{array}{l}\text { Municipality } \\
\text { name }\end{array}$} & \multicolumn{4}{|c|}{$\begin{array}{l}\text { Amount of groundwater pumped } \\
\text { per place }\left(\mathrm{m}^{3} \mathrm{yr}^{-1}\right)\end{array}$} \\
\hline & Case 1 & Case 2 & Case 3 & Case 4 \\
\hline District of Nishi & 3145 & 20969 & 104846 & 262114 \\
\hline District of Minato & 2218 & 14788 & 73941 & 184853 \\
\hline District of Showa & 3597 & 23978 & 119891 & 299728 \\
\hline District of Minami & 3125 & 20836 & 104181 & 260453 \\
\hline District of Kita & 3640 & 24266 & 121330 & 303326 \\
\hline District of Naka & 4166 & 27770 & 138852 & 347129 \\
\hline District of Nakagawa & 3369 & 22458 & 112289 & 280724 \\
\hline District of Higashi & 2848 & 18984 & 94922 & 237304 \\
\hline District of Atsuta & 2594 & 17299 & 86497 & 216242 \\
\hline District of Nakamura & 3079 & 20529 & 102646 & 256616 \\
\hline District of Mizuho & 3988 & 26590 & 132949 & 332373 \\
\hline City of Komaki & 1233 & 8217 & 41085 & 102711 \\
\hline City of Ichinomiya & 2419 & 16124 & 80622 & 201555 \\
\hline City of Kitanagoya & 3145 & 20965 & 104827 & 262067 \\
\hline City of Aisai & 1130 & 7533 & 37664 & 94159 \\
\hline City of Kiyosu & 1679 & 11196 & 55980 & 139950 \\
\hline City of Tsushima & 1873 & 12487 & 62435 & 156087 \\
\hline City of Konan & 5563 & 37089 & 185444 & 463609 \\
\hline City of Yatomi & 1466 & 9772 & 48860 & 122151 \\
\hline Town of Fuso & 1583 & 10553 & 52766 & 131916 \\
\hline City of Iwakura & 1301 & 8673 & 43366 & 108414 \\
\hline Town of Oharu & 2486 & 16573 & 82863 & 207159 \\
\hline Town of Oguchi & 3391 & 22606 & 113030 & 282575 \\
\hline Town of Shippo & 2119 & 14125 & 70624 & 176561 \\
\hline Town of Kanie & 1383 & 9220 & 46101 & 115252 \\
\hline Town of Miwa & 1909 & 12730 & 63648 & 159120 \\
\hline Town of Jimokuji & 1910 & 12733 & 63666 & 159164 \\
\hline Town of Toyoyama & 1098 & 7317 & 36584 & 91461 \\
\hline City of Inazawa & 3700 & 24669 & 123345 & 308363 \\
\hline Town of Haruhi & 849 & 5663 & 28313 & 70783 \\
\hline Village of Tobishima & 612 & 4083 & 20413 & 51032 \\
\hline City of Gifu & 1539 & 10260 & 51302 & 128254 \\
\hline City of Ogaki & 1488 & 9908 & 49542 & 123856 \\
\hline City of Kakamigahara & 4788 & 31918 & 159589 & 398972 \\
\hline City of Kuwana & 1761 & 11742 & 58710 & 146776 \\
\hline City of Hashima & 1509 & 10063 & 50315 & 125788 \\
\hline City of Mizuho & 2036 & 13572 & 67859 & 169648 \\
\hline City of Kaizu & 1375 & 9164 & 45818 & 114544 \\
\hline City of Motosu & 1334 & 8894 & 44470 & 111174 \\
\hline Town of Yoro & 795 & 5302 & 26509 & 66273 \\
\hline Town of Ikeda & 1799 & 11996 & 59982 & 149954 \\
\hline Town of Ono & 1030 & 6864 & 34320 & 85800 \\
\hline Town of Ginan & 567 & 3782 & 18912 & 47280 \\
\hline Town of Kasamatsu & 920 & 6136 & 30682 & 76704 \\
\hline Town of Godo & 1116 & 7439 & 37194 & 92984 \\
\hline Town of Kitagata & 656 & 4377 & 21883 & 54707 \\
\hline Town of Kisozaki & 929 & 6193 & 30966 & 77414 \\
\hline Town of Wanouchi & 1177 & 7844 & 39221 & 98053 \\
\hline Town of Anpachi & 2406 & 16040 & 80201 & 200502 \\
\hline Total & 103843 & 692289 & 3461455 & 8653634 \\
\hline
\end{tabular}



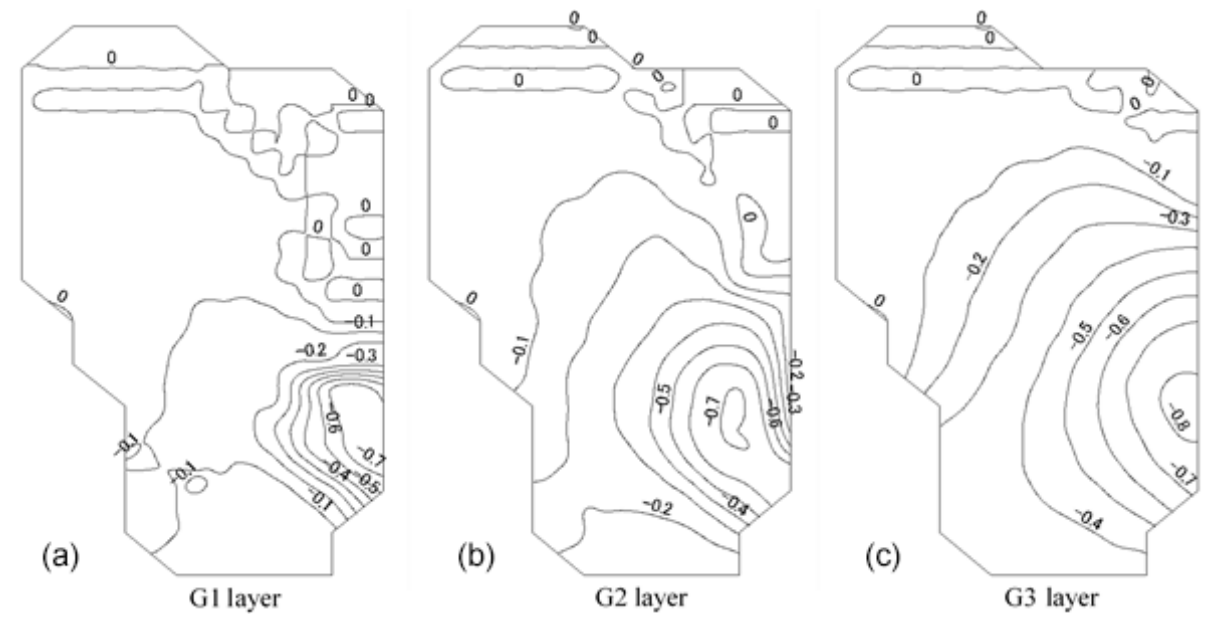

Figure 3. Groundwater level differences following well operation (Case 2) (m).

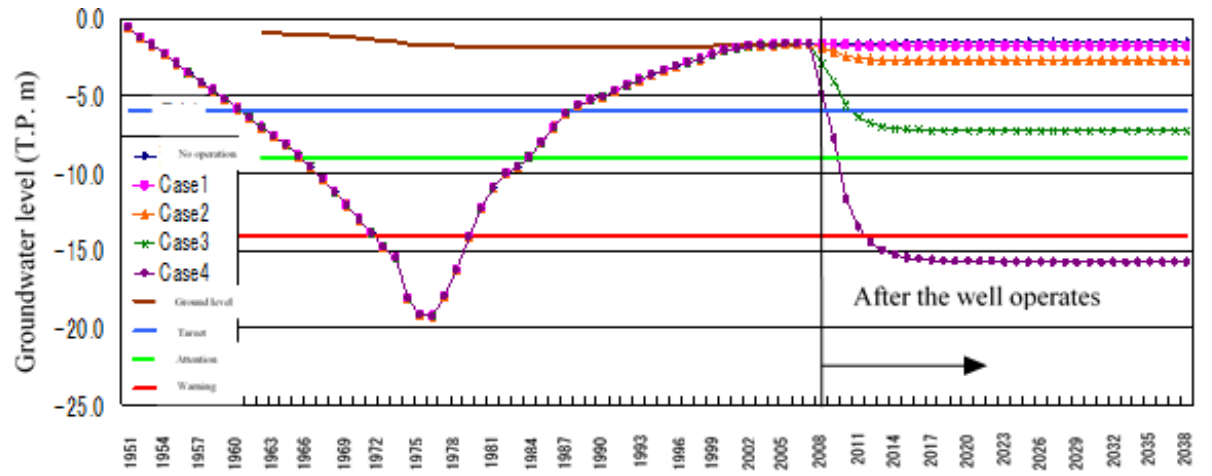

Figure 4. The yearly change of the groundwater level of Jushiyama observation well (G2 layer). “T.P.” refers to Tokyo Peil.

\section{Analytical results and consideration}

It is common for the G1, G2 and G3 layers, as shown in Fig. 3, that when groundwater levels during the period of well operation are compared, a radial decrease in the groundwater level centering on the vicinity of the city of Nagoya can be observed. Next, the yearly change of the groundwater level in the vicinity of Jushiyama observation well is shown in Fig. 4. The secular distortion in the amount of subsidence accumulated is shown in Fig. 5. Groundwater can be pumped without lowering groundwater level and without land subsidence in Case 1 and Case 2 even if 30 years have passed since the wells operated. In Case 3, the groundwater level fell below the management target for a safe groundwater level in the prefecture of Aichi, and it was forecast that the accumulated subsidence of 30 years was $6.8 \mathrm{~cm}$ after the new wells had operated.

However, the subsidence gradually tends to stop as the amount of the subsidence during a year is less than $1 \mathrm{~cm}$. It is thought that groundwater can be pumped, although there are some anxieties with regard to subsidence. In Case 4, when the lowering in the groundwater level after the well had been operating was remarkable and 30 years had passed since the well had operated, a remarkable accumulated subsidence of about $33.8 \mathrm{~cm}$ was forecast. Therefore, such groundwater withdrawal could not be done.

\section{Conclusions}

Here, the state of groundwater and ground-level changes in the future were predicted using a three-dimensional groundwater-flow analysis and a perpendicular onedimensional consolidation subsidence analysis in order to examine how a large area of groundwater should be managed. As a result, for the amount of the groundwater pumping of Case 1 and Case 2, it has been understood that it would be possible to pump groundwater without causing a remarkable subsidence. Moreover, if the amount of the groundwater pumping that exceeds Case 3, it has been understood that the possibility of remarkable subsidence occurs. Therefore, $100 \mathrm{Ld}^{-1}$ per person in Case 3 was assumed to be a critical yield of groundwater. It was judged that groundwater could be continuously pumped if it was fewer than this critical yield. 


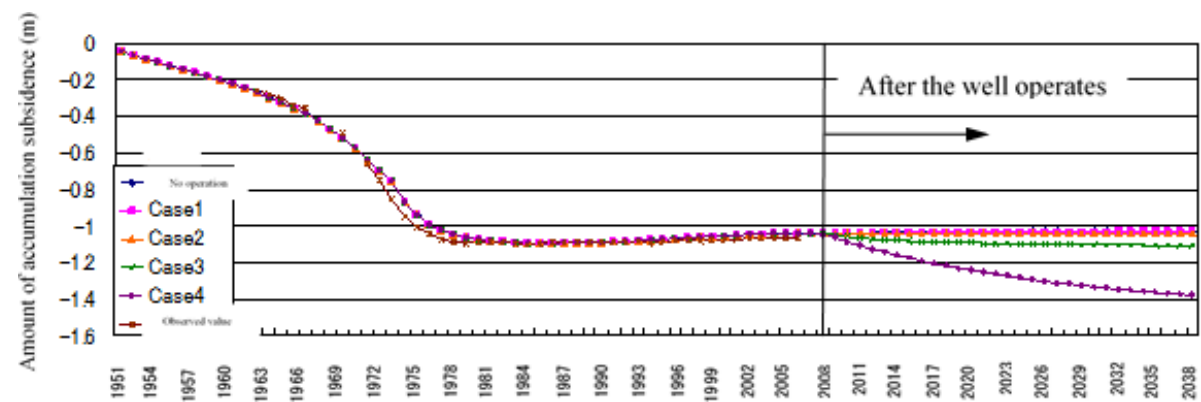

Figure 5. The yearly change of amount of accumulation subsidence in the vicinity of Jushiyama observation well.

Remarkable subsidence has occurred in the Nobi Plain in the past; therefore many of the clay layers are in a state of overconsolidation. This means that excessive subsidence may not occur even if a limited amount of groundwater were now to be pumped up. Moreover, the groundwater level forecast from the management target of a safe groundwater level is considerably higher in Case 1 and Case 2 in the G2 layer. Therefore, it is thought that steadier groundwater can be pumped by decreasing the pump discharge in the G1 layer and the G3 layer and increasing the pump discharge from the G2 layer.

Because pump discharge increases in proportion to the number of refuges and the size of the population, there is a comparatively remarkable drawdown in the groundwater level in a number of refugees in the vicinity of the populous city of Nagoya. The pump discharge in the vicinity of the city of Nagoya can be decreased along with an increase in the pump discharge in the vicinity of the city of Ogaki, with little reduction in the groundwater level. It is thought that this will mean that the possibility of subsidence decreases and can be used as a way to manage a large area of groundwater by transporting the shortfall to the vicinity of the city of Nagoya in the event of a disaster. Moreover, if groundwater of $100 \mathrm{Ld}^{-1}$ per person can be pumped, groundwater can be used as a water resource for improving water quality of the river and as a water for daily life after disaster. At this time, major subsidence has not occurred in the Nobi Plain.

Data availability. Data have been provided by Ministry of Health, Labour and Welfare (2007) and by Geospatial Information Authority of Japan, Ministry of Land, Infrastructure, Transport and Tourism (2019).
Competing interests. The author declares that there is no conflict of interest.

Special issue statement. This article is part of the special issue "TISOLS: the Tenth International Symposium On Land Subsidence - living with subsidence". It is a result of the Tenth International Symposium on Land Subsidence, Delft, the Netherlands, 17-21 May 2021.

Acknowledgements. I expresses my sincere gratitude to the organizations and people involved in the Tokai Three-Prefecture Investigation Committee on Land Subsidence.

\section{References}

Geospatial Information Authority of Japan, Ministry of Land, Infrastructure, Transport and Tourism: Situation of land subsidence of the Nobi Plain in 2018 (August, 2019), available at: https: //www.gsi.go.jp/common/000218175.pdf (last access: 17 April 2020), 2019 (in Japanese).

Kenji, D., Shigeharu, A., and Kouichi, M.: Geo-Environmental Considerations on Use and Control of Groundwater in Coastal Alluvial Plains, Japanese Association of Groundwater Hydrology, J. Groundwater Hydrol., 34, 263-282, 1992 (in Japanese).

Ministry of Health, Labour and Welfare: Earthquake measures manual decision indicator, available at: https://www.mhlw.go.jp/ topics/bukyoku/kenkou/suido/kikikanri/dl/chosa-0603_01a.pdf (last access: 17 April 2020), 2007 (in Japanese).

Yasuhiro, M., Kenji, D., and Shigeo, S.: Integrated groundwater management for appropriate use of groundwater, Japanese Society of Civil Engineers, Proc. of the 12th Global Environment Symposium, 95-100, 2005 (in Japanese). 